\title{
SEROPREVALENCE OF HEPATITIS C IN PREGNANT WOMEN IN GOVERNMENT MEDICAL COLLEGE, HALDWANI, UTTARAKHAND - A RETROSPECTIVE STUDY
}

\author{
Kanchan Rani1 ${ }^{1}$ Vandana Bisht ${ }^{2}$, Usha Rawat ${ }^{3}$
}

${ }^{1}$ Assistant Professor, Department Obstetrics and Gynaecology, Government Medical College, Haldwani, Uttarakhand. ${ }^{2}$ Associate Professor, Department Obstetrics and Gynaecology, Government Medical College, Haldwani, Uttarakhand. ${ }^{3}$ Professor, Department Obstetrics and Gynaecology, Government Medical College, Haldwani, Uttarakhand.

ABSTRACT

\section{BACKGROUND}

Information on hepatitis $\mathrm{C}$ virus infection in pregnant women in India is scarce since there are no universal guidelines for screening of Hepatitis $\mathrm{C}$ infection during antenatal checkup in India. Epidemiology of Hepatitis C infection during pregnancy was important for health planners and programme managers to effectively implement preventive and curative measures. Seroprevalence of Hepatitis $\mathrm{C}$ in pregnant women may be a good indicator of general population prevalence. Purpose of this study was to determine prevalence and to evaluate the need for routine antenatal screening for Hepatitis $\mathrm{C}$ infection among obstetric patients.

\section{MATERIALS AND METHODS}

This study was conducted in Government Medical College and Hospital at Haldwani in Uttarakhand. This is a retrospective study where data of all pregnant women who delivered at this hospital from April 2015 to March 2016 were collected and compiled with respect to age, parity, education, whether from rural or urban population.

\section{RESULTS}

Seropositivity of HCV was $0.43 \%$. One case was found positive for both Hepatitis C and Hepatitis B while another case was HIV positive along with Hepatitis $\mathrm{C}$ infection.

\section{CONCLUSION}

This study can be of help for obstetrician to formulate proper line of treatment and to take preventive measures to decrease vertical transmission. The data reinforces the need for establishing effective prevention programs which would lead to reduction in the prevalence of Hepatitis C infection.

\section{KEYWORDS}

Antenatal, Women, Hepatitis C, Vertical Transmission, Seroprevalence.

HOW TO CITE THIS ARTICLE: Rani K, Bisht V, Rawat U. Seroprevalence of hepatitis C in pregnant women in Government Medical College, Haldwani, Uttarakhand - A retrospective study. J. Evolution Med. Dent. Sci. 2016;5(85):6331-6334, DOI: 10.14260/Jemds/2016/1430

\section{BACKGROUND}

Viral Hepatitis during pregnancy is associated with high risk of maternal complication and has high rate of vertical transmission. Hepatitis $\mathrm{C}$ virus which before its identification was labelled as non-A, non-B Hepatitis is a linear single stranded positive sense 4600 nucleotide RNA virus. It belongs to the family Flaviviridae. It is transmitted by blood transfusion and percutaneous routes such as injectable drug use.

Global prevalence of Hepatitis $\mathrm{C}$ virus infection is $2 \%-3 \%$ with 130 - 170 million HCV positive people and most of them are chronically infected. Globally, HCV is implicated in $28 \%$ of cases of liver cirrhosis and $26 \%$ of cases of hepatocellular carcinoma which accounts for almost 5 lakh deaths per year. Epidemiology of Hepatitis $\mathrm{C}$ is varied among countries and the reported prevalence of Hepatitis $\mathrm{C}$ infection in pregnant women has not been extensively studied.

Financial or Other, Competing Interest: None.

Submission 18-06-2016, Peer Review 12-10-2016,

Acceptance 18-10-2016, Published 22-10-2016.

Corresponding Author:

Kanchan Rani,

D-6, Type-4

Government Medical College Campus,

Haldwani, Nainital-263139,

Uttarakhand.

E-mail: mukeshkumar2002@gmail.com

DOI: $10.14260 /$ jemds $/ 2016 / 1430$

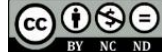

Despite low to moderate prevalence (1-1.5\%), India accounts for a significant global Hepatitis $\mathrm{C}$ infection due to large population and approximately 12 to 18 million population is infected.[1] Information on hepatitis C virus infection in pregnant women in India is scarce.

Pregnancy may be the only clinical access point for the women of reproductive age group in limited resources countries and knowing the HCV status of pregnant women will provide scope for counselling, take measures to reduce vertical transmission and management of HCV, followup and treatment of baby.

Both interferon and ribavirin are contraindicated during pregnancy. Viral clearance prior to next pregnancy increased the likelihood that women remain non-viraemic in pregnancy with consequent reduced risk of vertical transmission.

Few studies have reported highly significant incidence of intrahepatic cholestasis of pregnancy in Hepatitis $\mathrm{C}$ positive pregnant women. ${ }^{[2]} \mathrm{A}$ prospective Italian study suggested the need to investigate the HCV status in women with intrahepatic cholestasis of pregnancy.[2] The overall rate of mother to child transmission of HCV from HCV infected mother has been estimated to be $3 \%-5 \%$. If mother is known to be viraemic i.e. HCV RNA positive, rate of transmission increased. In one study from South India, perinatal transmission in HCV RNA positive women is as high as $25 \%$ [ $^{3]}$

Co-infection with HIV increased transmission to $19.4 \% .{ }^{[4]}$ 
At least one third of infants acquire HCV during the intrauterine period. Perinatal transmission is estimated to be as high as $40 \%-50 \%$ whereas postpartum transmission is rare. [5] Numerous risk factors for vertical transmission have been studied. In general, high viral load defined as at least $2.5 \times 10^{6}$ RNA copies/mL. HIV co-infection and invasive procedures are most important factors. [6] In general, maternal peripheral blood mononuclear cells infected by HCV, membrane rupture greater than 6 hours before delivery and instrumental vaginal delivery exposing the infant to maternal blood infected with HCV during vaginal delivery are associated with an increased risk of transmission.[7] Maternal liver dysfunction with abnormal ALT level in the year before pregnancy may reflect a more severe liver disease and may help in identifying mother with an increased risk of vertical transmission.[8] It would be prudent to avoid amniocentesis, instrumental vaginal delivery and prolonged rupture of membranes. A recent meta-analysis including 641 mother infant pair showed that caesarean section does not decrease perinatal HCV transmission from HCV RNA positive and HIV negative mother to infants. ${ }^{[9]}$ Thus, elective caesarean delivery should not be offered. HCV and HIV co-infected women should be offered elective caesarean section to prevent HIV transmission. ${ }^{[10]}$

After acute infection in $60-85 \%$ cases, there is persistent chronic hepatitis after 6 months. Among these, 5-20\% develop cirrhosis after 20 years and among these 25\% develop HCV end-stage liver disease after another 5 years.

Improved efficacy of new drug regimen requires reassessment of utility of universal screening for HCV in pregnant women.[11]

Seroprevalence of these infection among pregnant women may be a good indicator of general population prevalence. Such data are fundamental for health planner and care giver for evidence based intervention.

United States and Europe have expert guideline for screening of pregnant women for HIV, HBsAg and HCV to help appropriate management. In developing countries like India, no such uniform guidelines are available regarding $\mathrm{HCV}$ screening in pregnant women.

\section{MATERIALS AND METHODS}

A retrospective study was conducted to determine the prevalence of Hepatitis C virus among patients attending antenatal clinic in Government Medical College and Hospital, Haldwani, Uttarakhand.

Total 4202 antenatal cases were studied from April 2015 to March 2016. Data analysed were age, parity and patient's rural or urban background.

\section{Observation}

Total of 4202 antenatal cases were studied for HCV infection who attended antenatal clinic from April 2015 to March 2016. Antibody against HCV were found positive in 18 cases. Thus, overall prevalence of anti-HCV antibody was $0.43 \%$.

One woman was both HBsAg and HCV positive and in one case it was both HIV and HCV positive coinfection.

According to age, prevalence was maximum in 21 to 25 years of age group i.e. $0.64 \%$ closely following $0.49 \%$ in $26-30$ year of age and $0.47 \%$ in 31 to 35 year of age as shown in table 1.

\begin{tabular}{|c|c|c|c|}
\hline $\begin{array}{c}\text { Age Group } \\
\text { (Years) }\end{array}$ & $\begin{array}{c}\text { No. of } \\
\text { Pregnant } \\
\text { Women }\end{array}$ & $\begin{array}{c}\text { HCV } \\
\text { Positive }\end{array}$ & $\begin{array}{c}\text { Percentage } \\
\text { (\% Age) }\end{array}$ \\
\hline $15-20$ & 786 & 3 & 0.38 \\
\hline $21-25$ & 1086 & 7 & 0.64 \\
\hline $26-30$ & 1020 & 5 & 0.49 \\
\hline $31-35$ & 632 & 3 & 0.47 \\
\hline$>35$ & 578 & 0 & 0 \\
\hline \multicolumn{2}{|r}{ Table 1. Prevalence of HCV in Different Age Group } \\
\hline
\end{tabular}

Prevalence was maximum in multipara (parity $\geq 3$ ) i.e. $0.74 \%$ as shown in table 2 .

\begin{tabular}{|c|c|c|c|}
\hline Parity & $\begin{array}{c}\text { No. of Pregnant } \\
\text { Women }\end{array}$ & $\begin{array}{c}\text { HCV } \\
\text { Positive }\end{array}$ & $\begin{array}{c}\text { Percentage } \\
\text { (\% Age) }\end{array}$ \\
\hline 1 & 1356 & 5 & 0.36 \\
\hline 2 & 1638 & 4 & 0.24 \\
\hline$\geq 3$ & 1208 & 9 & 0.74 \\
\hline \multicolumn{2}{|c|}{ Table 2. Prevalence of HCV in Different Parities } \\
\hline
\end{tabular}

Prevalence was maximum in rural area i.e. $0.57 \%$ rather than in urban area i.e. $0.28 \%$ as shown in table 3.

\begin{tabular}{|c|c|c|c|}
\hline & $\begin{array}{c}\text { No. of Pregnant } \\
\text { Women }\end{array}$ & $\begin{array}{c}\text { HCV } \\
\text { Positive }\end{array}$ & $\begin{array}{c}\text { Percentage } \\
\text { (\% age) }\end{array}$ \\
\hline Rural & 2089 & 12 & 0.57 \\
\hline Urban & 2113 & 6 & 0.28 \\
\hline \multicolumn{2}{|c|}{ Table 3. Prevalence of HCV in Rural or Urban Areas } \\
\hline
\end{tabular}

\section{DISCUSSION}

According to National Centre for Disease Control (NCDC), prevalence of HCV in India is 1\% and WHO revealed that the prevalence of $\mathrm{HCV}$ is categorised and graded. High was greater than $3.5 \%$ while moderate was between $1.5 \%-3.5 \%$ and low was less than $1.5 \%$.

Prevalence in our study is very low as compared to a report from Egypt by Zahran K M et al $6.4 \%{ }^{[12]}$ and from Yemen by E.A. Murad et al $8.5 \%{ }^{[13]}$ but it is more than Mehta et al $0.19 \%{ }^{[14]}$ and Pyadala et al $0.21 \%{ }^{[15]}$ and Ganju et al $0 \% .^{[16]}$ Our result is comparable to Rudrapathy et al $0.6 \%[3]$ but less than Farhana et al 3.44\%[17] and Ashok Kumar et al 1.03\%. ${ }^{[18]}$ The highest prevalence of infection occurs among individuals of reproductive age group.[19,20] Age is a known risk factor for hepatitis $\mathrm{C}$ infection seropositivity, which has been reported to increase until age of 40 years and then decrease over time.[21,9] This can be explained by greater probability of exposure of these women to risk factors. In our study, prevalence was more in age group of 21 to 25 years followed by 26 to 30 and 31 to 35 years. Our findings were corresponding with the findings of the study.[22] where prevalence of hepatitis C increased up to age of 26 years and decreased after that. Lekin et al[23] have reported a higher mean parity of HCV positive patients in their study. Praveen $M$ et al[22] also found that prevalence of anti HCV among multiparous females were more than nulliparous females.

These results were similar with the results of our study in which prevalence was found to be more in multiparous women. Since this is a retrospective study so data could not be collected regarding history of risk factors for hepatitis $\mathrm{C}$ infection but several studies have found an association 
between prevalence of HCV infection and known risk factors i.e. blood transfusion, intravenous drug abusers, multiple sexual partners and homosexuality.[24,25] A study from North Italy shows the principle risk factor is associated with history of intravenous drug abuse (32\%) and exposure to blood products (24\%).[25] In a study from Pakistan, [26] past history of surgical procedure was found to be most important factor for transmission of hepatitis $C$ infection. In countries with poor resources, the risks of iatrogenic HCV infection were reported to be high.[27] This might explain the high prevalence of Hepatitis C in multiparous women having history of previous vaginal deliveries, caesarean sections and D\&E but various studies also have shown that 40 to $73 \%$ of women have no obvious risk factors for HCV infection. [25,28,29,30] So it has been found that selective antenatal screening based on risk factors failed to identify over half of the infected persons.[28] Also screening of asymptomatic pregnant women for hepatitis $\mathrm{C}$ virus infection is not cost effective. ${ }^{[31]}$ Routine screening is not recommended currently during pregnancy for asymptomatic women without risk factors.[29,32] Hepatitis C virus infection establishes a state of chronic infection in as many as $85 \%$ of acutely infected patients.[33] In India, anti-HCV antibodies are present in approximately 15 million people with a prevalence rate of 1.2 to $1.8 \% .{ }^{[34,35,36]} \mathrm{HCV}$ is the most infectious disease among intravenous drug users in India, so mortality and morbidity is more due to HCV than due to HIV among people who had a high risk factor such as sharing needles and syringes and also of other injecting related equipment because cost of treatment is very high and there is no government policy to screen these patients as in the case of HIV/AIDS. Universal screening for hepatitis $\mathrm{C}$ in pregnancy is not recommended. In our hospital, being a tertiary care centre, we have tendency to screen both for HCV and HBsAg serology.

However, routine HCV screening of antenatal patients is not done at $\mathrm{CHC}$, PHC and most of the private hospitals in our region. So our habit of screening for both HCV and HBsAg in antenatal women help us to identify patients with chronic HCV infection which could have remained unidentified until they progress into severe disease. These patients after delivery were followed for treatment to save them from chronic morbidity and mortality due to hepatitis $\mathrm{C}$ infection. It also helps us to follow their sexual partners and neonates for further evaluation for presence of hepatitis $C$ infection and treatment. It has been suggested that a minimum prevalence of $0.1 \%$ in general population justified screening for infection. ${ }^{[37]}$ In most of the studies including ours the prevalence of hepatitis $\mathrm{C}$ infection among pregnant women is more than $0.1 \%$. So universal screening of hepatitis $\mathrm{C}$ infection in antenatal women may need to be done to identify hepatitis $\mathrm{C}$ infection in pregnancy so that treatment can be started after delivery. More so because now cheaper and more effective drugs are available. It also allows us to take the opportunity to identify other person at risk like sexual partner and nonsexual partner because non-sexual intrafamilial mode of transmission of HCV has been reported.[38,39] Most important, it allows us to follow and treat the infants who might be infected with hepatitis $\mathrm{C}$ from vertical transmission. Thus, routine antenatal screening of hepatitis $\mathrm{C}$ infection will decrease the overall burden of chronic hepatitis $\mathrm{C}$ infection and its sequel related to it in general population.

\section{CONCLUSION}

Although prevalence in our study is low, it is prudent to follow universal screening of all antenatal women for HCV infection for proper followup, to take proper measures to prevent vertical transmission, followup of infants and to start proper treatment after delivery. It will prevent adverse effects of untreated Hepatitis C infection. It will also help women to become non-viraemic during her next pregnancy.

This data also reinforces the need for effective prevention programs which could lead to reduction in prevalence of Hepatitis C infection.

\section{REFERENCES}

1. Puri P, Anand AC, Saraswat VA, et al. Consensus statement of HCV task force of the Indian National Association for Study of the Liver (INASL). Part II: INASL recommendations for management of HCV in India. J Clin Exp Hepatol 2014;4(2):117-40.

2. Paternoster DM, Fabris F, Palu G, et al. Intra-hepatic cholestasis of pregnancy in hepatitis $\mathrm{C}$ virus infection. Acta Obstet Gynecol Scand 2002;81(2):99-103.

3. Parthiban R, Shanmugam S, Velu V, et al. Transmission of hepatitis $\mathrm{C}$ virus infection from asymptomatic mother to child in southern India. Int J Infect Dis 2009;13(6):e394400.

4. Roberts EA, Yeung L. Maternal-infant transmission of hepatitis C virus infection. Hepatology 2002;36(5 Suppl 1):S106-13.

5. Hayashida A, Inaba N, Oshima K, et al. Re-evaluation of the true rate of hepatitis $\mathrm{C}$ virus mother-to-child transmission and its novel risk factors based on our two prospective studies. J Obstet Gynaecol Res 2007;33(4):417-22.

6. Mast EE, Hwang LY, Seto DS, et al. Risk factors for perinatal transmission of hepatitis $\mathrm{C}$ virus (HCV) and the natural history of HCV infection acquired in infancy. J Infect Dis 2005;192(11):1880-9.

7. Indolfi G, Resti M. Perinatal transmission of hepatitis C virus infection. J Med Virol 2009;81(5):836-43.

8. England K, Thorne C, Newell ML. Vertically acquired paediatric coinfection with HIV and hepatitis $\mathrm{C}$ virus. Lancet Infect Dis 2006;6(2):83-90.

9. Chehreh GME, Tabatabaei SV, Khazanehdari S, et al. Effect of cesarean section on the risk of perinatal transmission of hepatitis C virus from HCV-RNA+/HIV- mothers: a metaanalysis. Arch Gynecol Obstet 2011;283(2):255-60.

10. Pembrey L, Newell ML, Tovo PA, et al. The management of HCV infected pregnant women and their children European paediatric HCV network. J Hepatol 2005;43(3): 515-25.

11. Prasad MR, Honegger JR. Hepatitis C virus in pregnancy. Am J Perinatol 2013;30(2):149-59.

12. Zahran KM, Badary MS, Agban MN, et al. Pattern of hepatitis virus infection among pregnant women and their newborns at the Women's health center of Assiut University, upper Egypt. Int J Gynaecol Obstet 2010; 111(2):171-4.

13. Murad EA, Babiker SM, Gasim GL, et al. Epidemiology of hepatitis $\mathrm{B}$ and hepatitis $\mathrm{C}$ virus infections in pregnant women in Sana'a, Yemen. BMC Pregnancy and Childbirth 2013;13:127. 
14. Mehta KD, Antala S, Mistry M, et al. Seropositivity of hepatitis B, hepatitis C, syphilis, and HIV in antenatal women in India. J Infect Dev Ctries 2013;7(11):832-7.

15. Pyadala N, Maity SN, Kothapalli J, et al. Seroprevalence of HCV infection among pregnant women in a rural teaching hospital, Sangareddy. International Journal of Research and Development in Pharmacy and Life Sciences 2016;5(4):2251-4.

16. Ganju SA, Goel A. Hepatitis C virus activity in Shimla - a preliminary report. Indian J Med Microbiol 2001;19(4):227.

17. Shaikh F, Naqvi SQH, Jilani K, et al. Prevalence and risk factors for Hepatitis C virus during pregnancy. Gomal Journal of Medical Sciences 2009;7(2):86-8.

18. Kumar A, Sharma KA, Gupta RK, et al. Prevalence \& risk factors for hepatitis $\mathrm{C}$ virus among pregnant women. Indian J Med Res 2007;126(3):211-5.

19. Centers for Disease Control and Prevention. Recommendations for prevention and control of hepatitis $\mathrm{C}$ virus (HCV) infection and HCV-related chronic disease. Morb Mortal Wkly Rep 1998;47(RR-19):1-39.

20. Wasley AD, Alter MJ. Epidemiology of hepatitis C: geographic differences and temporal trends. Semin Liver Dis 2000;20(1):1-16.

21. Stevens CE, Taylor PE, Pindyck J, et al. Epidemiology of hepatitis $C$ virus: a preliminary study in volunteer blood donors. JAMA 1990;263(1):49-53.

22. Parveen M, Smiti N, Vani M, et al. Prevalence of HIV, Hepatitis B, Hepatitis $C$ in pregnancy at tertiary care center of Northern India. Adv Res Gastroentero Hepatol 2016;1(4)1-3.

23. Leikin EL, Reinus JF, Schmell E, et al. Epidemiologic predictors of hepatitis $\mathrm{C}$ virus infection in pregnant women. Obstet Gynecol 1994;84(4):529-34.

24. Silverman NS, Jenkin BK, Wu C, et al. Hepatitis virus in pregnancy: seroprevalence and risk factors for infection. Am J Obstet Gynecol 1993;169(3):583-7.

25. Conte D, Fraquelli M, Prati D, et al. Prevalence and clinical course of chronic hepatitis $\mathrm{C}$ virus (HCV) infection and rate of HCV vertical transmission in a cohort of 15,250 pregnant women. Hepatology 2000;31(3):751-5.

26. Jaffery T, Tariq N, Ayub R, et al. Frequency of hepatitis C in pregnancy and pregnancy outcome. J Coll Physicians Surg Pak 2005;15(11):716-9.
27. Hutin YJF, Hauri AM, Armstrong GL. Use of injections in healthcare settings worldwide, 2000: literature review and regional estimates. BMJ 2003;327(7423):1073-8.

28. Ward C, Tudor-Williams G, Cotzias T, et al. Prevalence of hepatitis $\mathrm{C}$ among pregnant women attending an inner London obstetric department: uptake and acceptability of named antenatal testing. Gut 2000;47(2):277-80.

29. National Institutes of Health. National Institutes of Health Consensus Development Conference Statement: management of hepatitis C: 2002-June 10-12, 2002. Hepatology 2002;36(5 Suppl 1):S3-S20.

30. Zanetti AR, Tanzi E, Newell ML. Mother-to-infant transmission of hepatitis C virus. J Hepatol 1999;31(Suppl 1):96-100.

31. Plunkett BA, Grobman WA. Routine hepatitis C virus screening in pregnancy: a cost-effectiveness analysis. Am J Obstet Gynecol 2005;192(4):1153-61.

32. ACOG Educational Bulletin. Viral hepatitis in pregnancy. Number 248, July 1998. American College of Obstetricians and Gynecologists. Int J Gynecol Obstet 1998;63(2):195202.

33. Karki S, Ghimire P, Tiwari BR, et al. Trends in hepatitis B and hepatitis $\mathrm{C}$ seroprevalence among Nepalese blood donors. Jpn J Infect Dis 2008;61(4):324-6.

34. Panigrahi AK, Panda SK, Dixit RK, et al. Magnitude of hepatitis $C$ virus infection in India: prevalence in healthy blood donors, acute and chronic liver disease. J Med Virol 1997;51(3):167-74.

35. Batham A, Narula D, Toteja T, et al. Systematic review and meta-analysis of prevalence of hepatitis B in India. Indian Pediatr 2007;44(9):663-74.

36. Overview of Hepatitis C problem in countries of the SouthEast Asia region. http://www.searo.who.int/en.htm.

37. Thornton AC, Delpech V, Kall MM, et al. HIV testing in community settings in resource-rich countries: a systematic review of the evidence. HIV Med 2012;13(7): 416-26.

38. Gupta S, Gupta R, Joshi YK, et al. Role of horizontal transmission in hepatitis $B$ virus spread among household contacts in north India. Intervirology 2008;51(1):7-13.

39. Thakur V, Kazim SN, Guptan RC, et al. Molecular epidemiology and transmission of hepatitis $\mathrm{B}$ virus in close family contacts of HBV-related chronic liver disease patients. J Med Virol 2003;70(4):520-8. 